\title{
非小細胞肺癌に対する化学放射線療法の長期成績の検討
}

\author{
藤原一央 ${ }^{1} \cdot$ 芥川 茂 $2 \cdot$ 川上 明 2 - 佐々木義行 2
}

要旨一一目的. 局所進行非小細胞肺癌に対する化学放射線療法 (以下 CRT)の長期成績について検討した.また，CRT 後に手術が施行された症例 (手術群) との比較検討も行った. 対象・方法. 1992 年 1 月〜2001 年 4 月までに, CRT を施行された Stage II ・III 期非小細胞肺癌 82 例 (CRT 群). 化学療法は, cisplatin $\left(20 \mathrm{mg} / \mathrm{m}^{2}:\right.$ day 1〜 5, 22〜26), VP$16\left(30 \mathrm{mg} / \mathrm{m}^{2}\right.$ : day 1〜5，22〜26) あるいは cisplatin（10 mg/body）連日少量投与が使用された. 放射線治療は，1998 年までは総線量 $60 \mathrm{~Gy}$ ，それ以降は原則 $66 \mathrm{~Gy}$ を照射した. 手術群は 32 例で, CRT 終了 4 5 週間後に手術が施行され た. 結果. CRT 群, 手術群のそれぞれの生存率は, MST: 17 力月, 14 力月, 2 生：41.8\%, 40.2\%, 5 生：19.4\%, $22.1 \%$ であった. CRT 群の grade 3 以上の有害事象は, 白血球減少 $34.1 \%$, 血小板減少 $14.6 \%$, 食道炎 $2.4 \%$, 放射線肺炎 $11.0 \%$ であった. 結語. 非小細胞肺癌に対する CRT は, 従来の治療法に比して長期生存が期待でき有害事象も許容範囲で あった.（肺癌. 2004;44:225-232）

索引用語—— 非小細胞肺癌, 集学治療, 化学放射線療法

\section{Long-term Follow-up Results of Concurrent Chemoradiotherapy for Non-small Cell Lung Cancer}

\author{
Kazuhisa Fujiwara ${ }^{1}$; Shigeru Akutagawa²; Akira Kawakami ${ }^{2}$; Yoshiyuki Sasaki ${ }^{2}$
}

\begin{abstract}
Objective. We evaluted long-term follow-up results of concurrent chemoradiotherapy (CRT) for locally advanced non-small cell lung cancer (NSCLC), and patients underwent surgery after CRT. Patients and Methods. Between January 1992 and April 2001,82 patients with histologically proven NSCLC, stage II-III, were entered into this study. Chemotherapy consisted of cisplatin (20 mg/m² on days $1-5,22-26)$ and VP-16 (30 mg/m² on days 1-5, 22-26) or cisplatin $(10 \mathrm{mg} /$ body $)$ daily. Conventional thoracic radiotherapy was delivered at 2 Gy daily reaching a total dose of 60 Gy or 66 Gy. Thirty-two patients underwent surgery 4-5 weeks after CRT. Results. The median survival time, 2 and 5-year survival rates of 82 patients who underwent CRT and 32 patients who underwent surgery after CRT were 17 months, 41.8\%, 19.4\% and 14 months, 40.2\%, 22.1\%. The most common grade 3 and 4 toxicities included leukopenia $(34.1 \%)$, thrombocytopenia $(14.6 \%)$, esophagitis $(2.4 \%)$, and radiation pnuemonitis $(11.0 \%)$. There were no treatment related deaths. Conclusions. Our study of concurrent chemoradiotherapy for NSCLC demonstrated the potential to provide long-term survival and the safety. (JJLC. 2004;44:225-232)
\end{abstract}

KEY WORDS — Non-small cell lung cancer, Combined modality therapy, Concurrent chemoradiotherapy

国立病院機構京都医療センター 1 放射線科, 2 呼吸器科. 別刷請求先: 藤原一央, 国立病院機構京都医療センター放射線 科, ₹612-8555 京都市伏見区深草向畑町 1-1.

Department of ${ }^{1}$ Radiology, ${ }^{2}$ Respiratory Medicine, National Hospital Organization Kyoto Medical Center, Japan.
Reprints: Kazuhisa Fujiwara, Department of Radiology, National Hospital Organization Kyoto Medical Center, 1-1 Mukaihata-cho, Fukakusa, Fushimi-ku, Kyoto 612-8555, Japan. Received May 6, 2004; accepted July 15, 2004. (C) 2004 The Japan Lung Cancer Society 


\section{はじめに}

進行非小細胞肺癌は, 潜在性のリンパ節転移や血行性 転移が存在し，その子後は不良である．近年，化学療法 と放射線療法を同時に施行することにより，潜在的な転 移の制御と放射線の局所に対する増感効果を期待した， concurrent chemoradiotherapy（以下 CRT）の報告が数多 くなされ,標準治療となりつつある.1-3 しかし,併用化学 療法や照射線量・照射方法あるいは長期成績の検討な ど, まだ解決するべき問題も多い.

今回, 当院で CRT を施行された進行非小細胞肺癌症例 の長期成績を分析し, 今後の問題点の検討を行った.ま た, CRT 後に手術が施行された症例との比較検討も行っ た。

\section{対象と方法}

1992 年 1 月から 2001 年 4 月までに, 当院で CRT を施 行した進行非小細胞肺癌症例 119 例について retrospective に検討を行った. 年齢は 37 歳から 84 歳（平均 64.8 歳）であった。 そのうち, 治療が完遂した症例は 114 例 で，CRT のみを施行した症例（以下 CRT 群）は 82 例, CRT 終了後 down stage が得られ，手術を施行した症例 (以下手術群) は 32 例であった.

CRT 群の年齢は 40 歳から 84 歳 (平均 66.6 歳). 性別 は, 男性 64 例, 女性 18 例. 病理組織型は, 扁平上皮癌 53 例, 腺癌 25 例, 大細胞癌 4 例. 病期分類は, IIB 期 3 例, III 期 79 例 (IIIA 期 23 例, IIIB 期 56 例), performance status (以下 PS) は, 0〜1:74 例, $2: 8$ 例であった.

手術群の年歯令は 37 歳から 75 歳 (平均 59.9 歳). 性別 は, 男性 28 例, 女性 4 例. 病理組織型は扁平上皮癌 27 例, 腺癌 4 例, 大細胞癌 1 例. CRT 前の病期分類は II 期 6 例, III 期 26 例 (IIIA 期 12 例, IIIB 期 14 例). PS は，全例 $0 〜 1$ であった.

治療方法は Figure 1 に示すように化学療法を day 1〜
5, 22〜25に cisplatin (以下 CDDP) $\left(20 \mathrm{mg} / \mathrm{m}^{2}\right), \mathrm{VP}-16$ $\left(30 \mathrm{mg} / \mathrm{m}^{2}\right)$ を点滴静注した。 もし，1回目の投与で骨髄 抑制が強く出現する場合は，2 回目の投与量を 50 ～75\% に減量するか, あるいは 1 週間延期して施行した. 治療 完遂 114 例中 103 例（手術群全例を含む）に施行されて いた. また, 75 歳以上の高齢者や PS 2 症例, あるいは軽 度の合併症を有している症例に対しては, CDDP (10 mg/ body）の照射日連日投与を併用できる範囲内で施行し た.こちらは 114 例中 11 例に施行されていた. 放射線療 法は，10 MV X 線照射装置を使用して day 1 から開始し た. 化学療法施行日は, 化学療法開始 1 2 時間後から放 射線療法を施行した. 1 回 2 Gy で週 5 回, 総線量は 1998 年までは $60 \mathrm{~Gy}, 1999$ 年からは $66 \mathrm{~Gy}$ を split course を 設定せずに施行した.40〜 46 Gy 時点で CT を参考に春髄 遮断と照射野縮小を行った。

治療の効果判定は, CRT 終了 3〜4 週間後の CTにて, 肺癌取扱い規約の効果判定基準に準じて行った．治療の 毒性評価には, NCI-Common Toxicity Criteria を使用し た. 治療開始からの生存率の評価は Kaplan-Meier 法を使 用し，有意差検定は log-rank testにて行った。

手術は, CRT 終了 3 週間後に CTにて治療効果判定を 行い, CT 上 down stage が得られ PS や呼吸機能に問題 のない症例に対して, CRT 終了 4〜5 週間後に施行され た. 手術後の効果判定は, 肺癌取扱い規約の組織学的判 定基準にて行った.

\section{結 果}

\section{治療効果}

CRT 群の治療効果判定は, 82 例中 complete response (以下 CR) 12 例, partial response (以下 PR) 54 例, no change（以下 NC） 16 例で $80.5 \%$ と高い奏効率を示した (Table 1). 期 別では, IIB 期：PR 2 例 (66.7\%), IIIA 期 : CR 6 例, PR 13 例 (82.6\%), IIIB 期 : CR 6 例, PR 39 例 $(80.4 \%)$ であった. 組織別では, 扁平上皮癌：

\section{- Radiation Total 66 Gy/2 Gy/day (-199960 Gy) \\ - Chemotherapy}

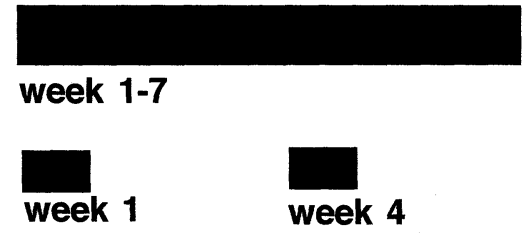

(1) CDDP $20 \mathrm{mg} / \mathrm{m}^{2}$ : day $1-5,22-26$

VP-16 $30 \mathrm{mg} / \mathrm{m}^{2}$ : day $1-5,22-26$

\section{(2) CDDP $10 \mathrm{mg} / \mathrm{body} / \mathrm{day}$}

Figure 1. Chemoradiotherapy. 
CR 6 例, PR 41 例 $(88.7 \%)$, 腺癌 : CR 4 例, PR 11 例 $(60.0 \%)$, 大細胞癌：CR 2 例, PR 2 例 (100\%)であった. 手術群の組織学的効果判定は, 32 例中 Ef3；11 例, Ef2；18 例, Ef1；3 例で, Ef3, Ef2 を有効例として検討 すると, 奏効率は $90.6 \%$ であった (Table 1). 組織別では, 扁平上皮癌：Ef3；10 例，Ef2；14 例 $(88.8 \%)$, 腺癌： Ef3； 1 例, Ef2；3 例 $(100 \%)$, 大細胞癌 : Ef2； 1 例 (100\%) であった。

Table 1. Local Response Rate

\begin{tabular}{cc}
\hline CRT group (by CT) & Operation group (by histology) \\
CR: 12 & Ef3: 11 \\
PR: 54 & Ef2: 18 \\
NC: 16 & Ef3: 3 \\
\hline Total: 82 & Total: 32 \\
(RR: $80.5 \%)$ & (RR: $90.6 \%)$ \\
\hline
\end{tabular}

CR: complete response, PR: partial response, NC: no change, RR: response rate.

Table 2. Pattern of First Recurrence

\begin{tabular}{ccc}
\hline & CRT group & Operation group \\
\hline Local recurrence & 39 & 0 \\
\hline Metastasis & & \\
\hline Brain & 12 & 4 \\
Liver & 3 & 5 \\
Lung & 1 & 5 \\
Bone & 8 & 0 \\
Others & 5 & 2 \\
\hline
\end{tabular}

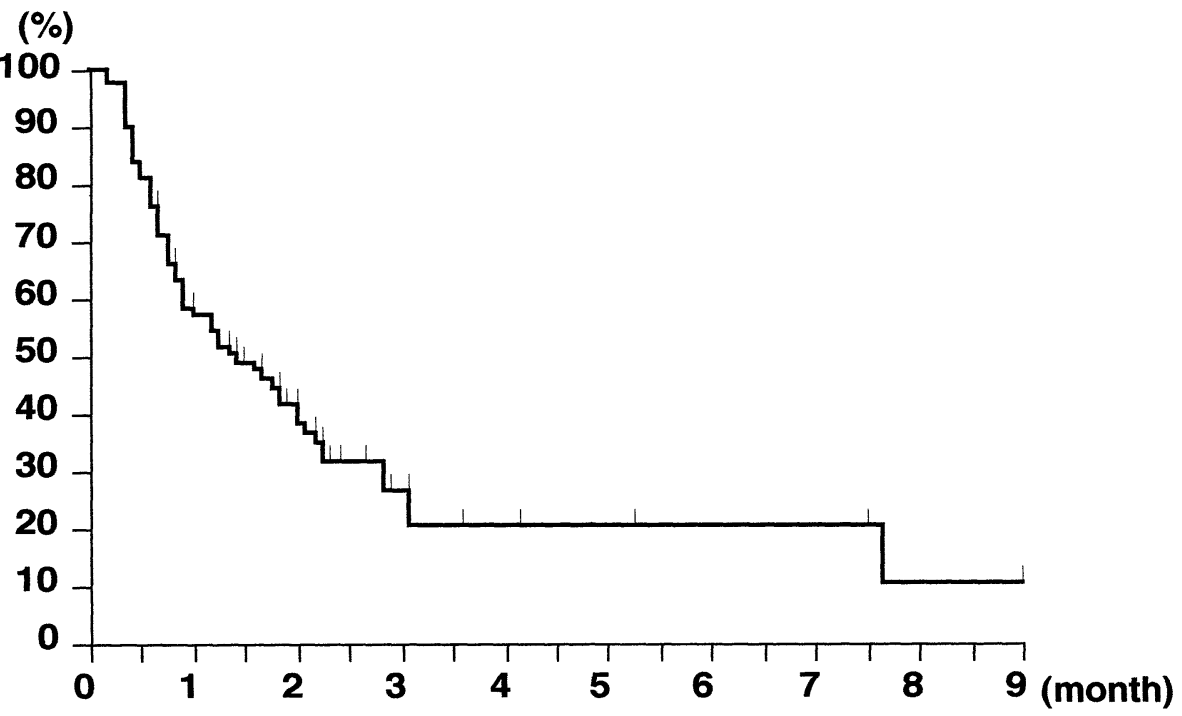

Figure 2. Overall survival: CRT group. 


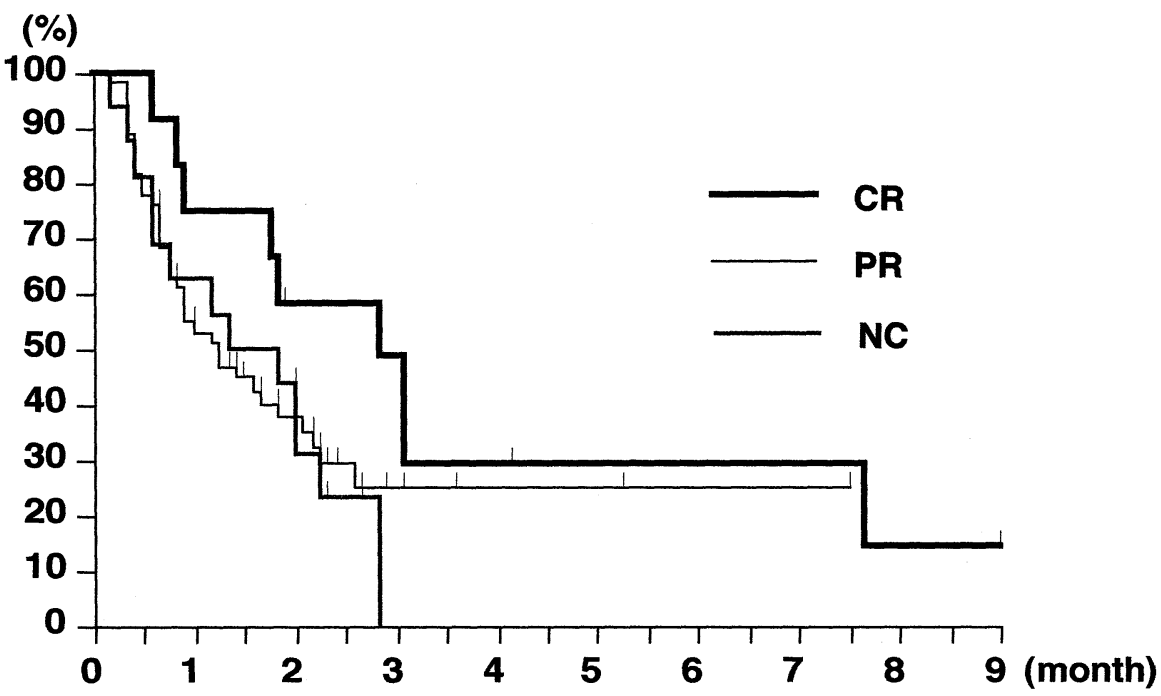

Figure 3. Survival rate: $\mathrm{CR}$ vs $\mathrm{PR}$ and NC.

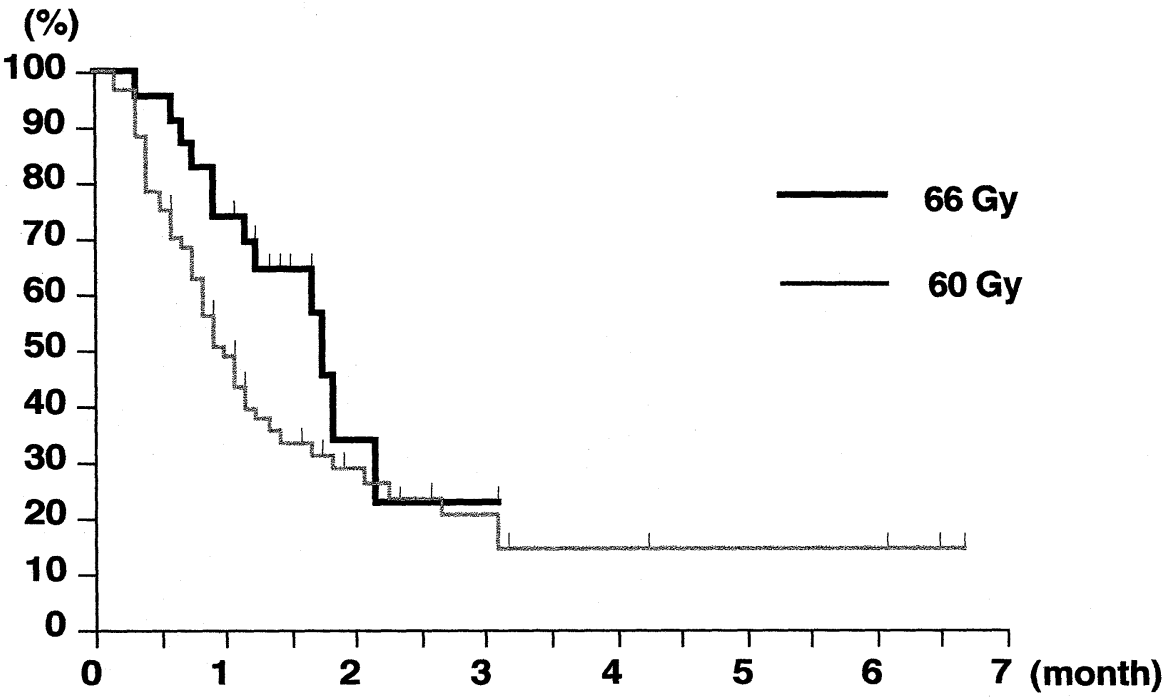

Figure 4. Survival rate: 60 Gy vs 66 Gy.

射線量を $60 \mathrm{~Gy}$ から $66 \mathrm{~Gy}$ に増量して照射を施行してい る. 現在, 29 症例に対して 66 Gy を照射しているが, $\mathrm{CR}$ 5 例, PR 16 例, NC 8 例で, MST 22 カ月, 2 生 $50.1 \%$ で あった. $60 \mathrm{~Gy}$ 照射症例では, MST 12 力月, 2 生 $36.1 \%$, 5 生 $21.8 \%$ で, 2 生については $66 \mathrm{~Gy}$ 照射症例が, $60 \mathrm{~Gy}$ 照射症例よりも有意に良好であった $(\mathrm{P}<0.01)$ (Figure 4).

手術群の手術関連死を含めた全体の成績は, MST 14 カ月, 2 生 $40.2 \%, 5$ 生 $22.1 \%$ であった (Figure 5). 手術 関連死を除外した成績は，MST 15 カ月，2生 42.9\%，5 生 $23.6 \%$ であった. CRT 群と手術群の生存率を比較した
ところ, 2 生では手術群が良好な傾向にあったが, 5 生で は有意差は認められなかった $(\mathrm{P}=0.61)$ (Figure 6). 組織 学的効果別にみると, Ef 3 は MST 12 力月, 2 生 45.5\%, 5 生 $27.3 \%$. Ef 2 は, MST 14 力月, 2 生 $37.5 \%, 5$ 生 15.6\%. Ef 1 は, MST 9 カ月, 2 生・5 生は $33.3 \%$ であっ た。

\section{有害事象}

CRT 群での有害事象を Table 3 に示した。骨髄抑制の grade 3 以上の事象は, 白血球減少 28 例 $(34.1 \%)$, 血小 板減少 12 例 $(14.6 \%)$ ，貧血 14 例（17.1\%）であった. その他の grade 3 以上の事象としては, 嘔気・嘔吐 20 


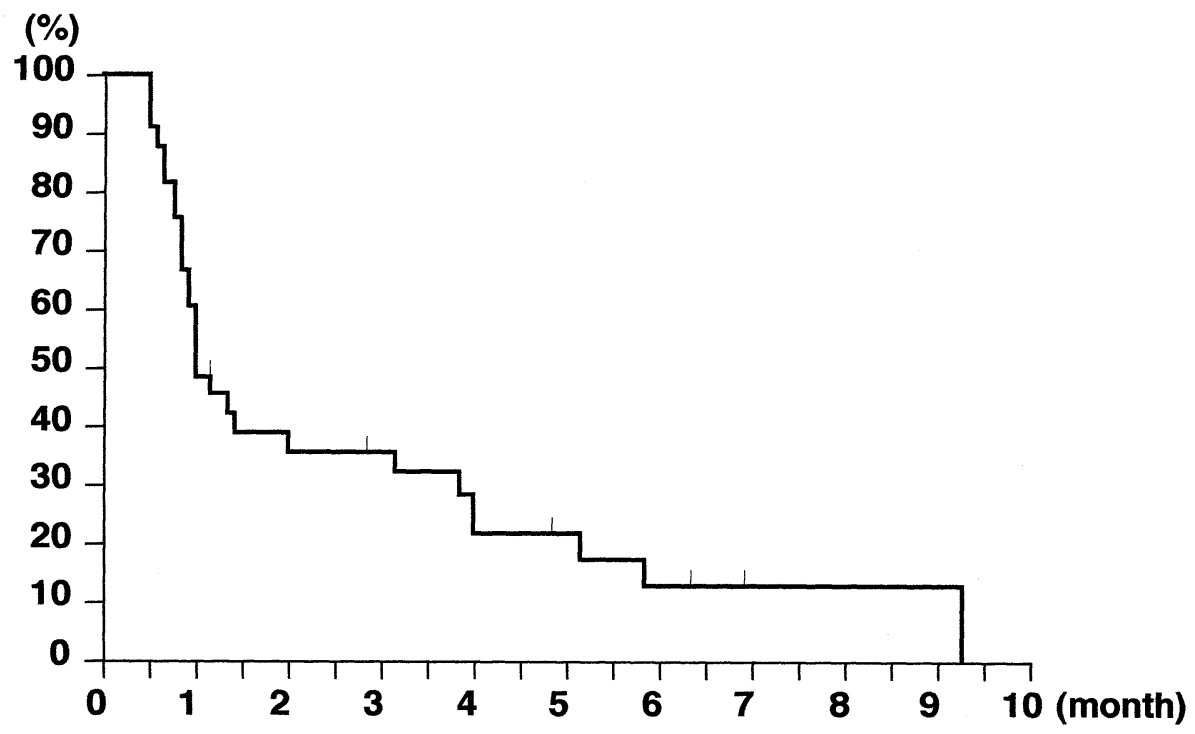

Figure 5. Overall survival: operation group.

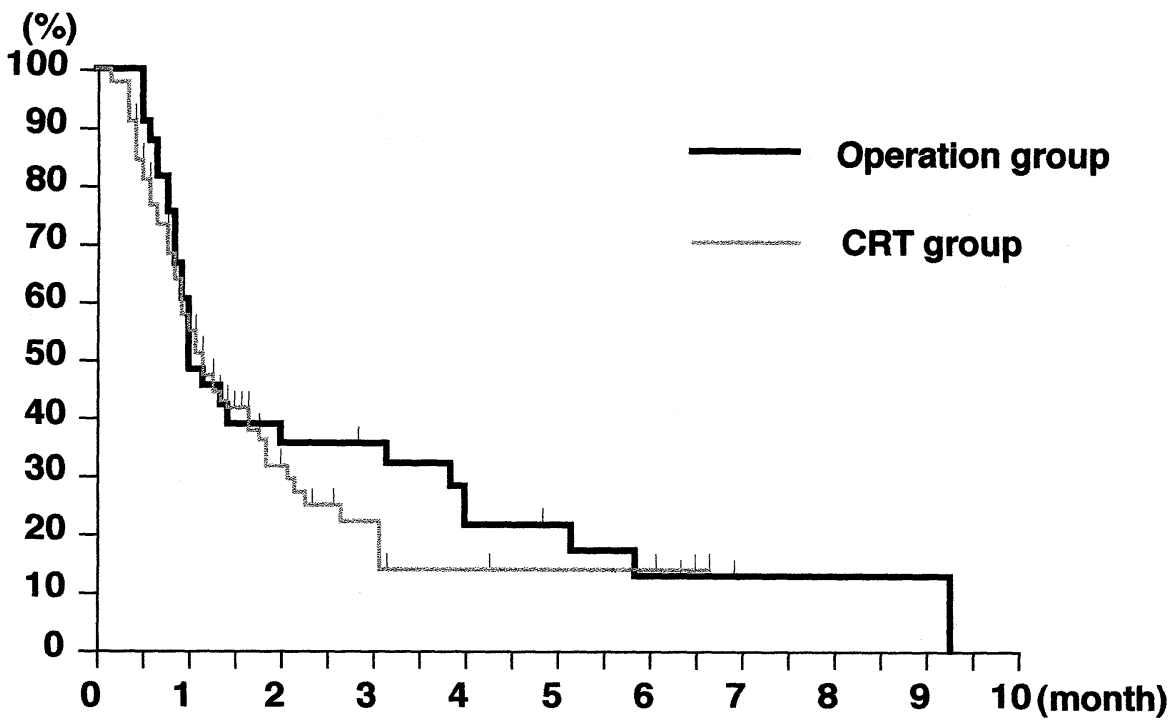

Figure 6. Survival rate: operation group vs CRT group.

例 $(24.4 \%)$ ，放射線食道炎 2 例 $(2.4 \%)$ ，放射線皮虐炎 2 例 $(2.4 \%)$, 放射線肺炎 9 例 $(11 \%)$ であった. grade 4 の事象は放射線肺炎の 2 例に認められたが，それ以外 の事象では認められなかった。治療による関連死は認め られなかった。

治療の脱落例は 5 例であったが，原因としては治療中 に肺結核等の感染症発現 3 例, 重度の筫血 1 例, 患者様 本人の中止希望 1 例であった。

手術群の手術に関連した合併症は，60 Gy 照射症例 29 例中 9 例 (31.0\%)，66 Gy 照射症例 3 例中 1 例 (33.3\%), 全体の $31.3 \%$ と高率に認められた (Table 4). このうち死
亡例は気管・気管支瘻 4 例, 肺静脈出血 1 例であった.

\section{考 察}

肺癌の $75 \%$ 以上を占める非小細胞肺癌は, その多くが 局所進行肺癌であり，また高率に遠隔転移を伴うことか ら，長期生存を得るには局所制御とともに潜在的な遠隔 転移のコントロールが重要となる，そこで，有効な化学 療法と放射線療法の併用により，潜在的な遠隔転移の制 御と局所一の増感効果が期待され, 併用療法による臨床 試験が数多く検討されている．併用方法としては，導入 化学療法後に放射線療法を施行する sequential chemo- 
Table 3. Commom Toxicities

\begin{tabular}{lcccc}
\hline \multicolumn{1}{c}{ Toxicity } & $0 / 1$ & 2 & 3 & 4 \\
\hline Leukopenia & 15 & 39 & 28 & 0 \\
Thrombocytopeina & 58 & 12 & 12 & 0 \\
Anemia & 40 & 28 & 14 & 0 \\
Anorexia & 30 & 32 & 20 & 0 \\
Esophagitis & 39 & 41 & 2 & 0 \\
Dermatitis & 71 & 11 & 0 & 0 \\
Pneumonitis & 57 & 16 & 7 & 2 \\
\hline
\end{tabular}

Table 4. Postoperative Complications

\begin{tabular}{lc}
\hline Bronchial Fistula & 4 \\
PV-bleeding & 1 \\
Lung Abscess & 2 \\
Pneumonia & 2 \\
Delayed Healing & 1 \\
\hline & $10 / 32(31.3 \%)$ \\
\hline
\end{tabular}

radiotherapy (以下 SRT) と化学療法と放射線療法を同時 に併用する CRT がある. CDDPをはじめとするプラチナ 製剤の出現以降, CDDPを中心とした多剤併用化学療法 によって, 進行非小細胞肺癌においても高い奏効率と生 存期間の延長が得られるようになった。 その後, SRT と放射線療法単独との比較試験が多数行われ, SRT が放 射線療法単独に比して, 有用であることが検証された. $4-8$ また, いくつかのメタアナリシスも行われており, 化学 療法＋放射線療法による延命効果が確認されている.9-11 そこで考えられるのが，抗癌剤と放射線を同時に併用す る CRTであるが, 当初は有害事象の増強が懸念された. 実際, full dose の抗癌剂と放射線療法の併用が良いのか, 放射線増感剂として抗癌剂を少量分割で投与するのが良 いのかが問題となった. Schaake-Koning ら 2 が, 少量 CDDP と胸部放射線照射の CRT が放射線療法単独に比 べて,有意に生存期間を延長させることを報告して以来, 放射線増感効果を狙っての少量のプラチナ製剤の連日あ るいは毎週の投与と胸部放射線療法の臨床試験が多数行 われた. しかし, Schaake-Koning らの報告以降, その有 用性を証明する報告はあまりみられていない。その後の Furuse ら 1 の報告では, full dose の抗癌剤併用による SRT と CRT の 314 例での比較試験を行い, 奏効率, 生存 率ともに CRT の方が良好で, 毒性も耐用可能であったと 報告している，この報告以降， CRT の臨床試験が数多く 施行されており, その有用性が報告されるにつれ進行非 小細胞肺癌の標準治療になりつつある.12,13

今回の我々の報告は, single-arm の報告であり比較試
験ではないが, CRT 群の治療効果は, 82 例中 CR 12 例, PR 54 例, NC 16 例で 80.5\% と高い奏効率を示した. 全体 の MST は 17 カ月, 2 生は $41.8 \%, 5$ 生は $19.4 \%$ と従来の 治療法や他の CRT の報告1-3,11-13 と比較しても遜色のな い成績であった. また, grade 4 以上の有害事象も放射線 肺炎の 2 例に認められたが，治療による関連死は認めら れなかったことから, CRTは進行非小細胞肺癌に対して 安全で有効な治療法であることが再確認された.

肺癌治療の場合，局所制御が非常に重要となるのは周 知の事実であるが, 今回も $\mathrm{CR}$ 症例は, $\mathrm{PR} \cdot \mathrm{NC}$ 症例と比 較して有意に予後良好であった. 従って, 局所制御を高 めるためには, 放射線療法が重要な役割を担うと思われ るが, CRTにおける照射線量や照射方法についての明確 なコンセンサスは得られていない. 現在, 照射法として は通常分割法で split-course を設定せずに照射してい る. Kubota ら 13 は, split-course の設定を推奨している が，有害事象に大きな差はなく split-course の設定は必 要ない印象である. 照射総線量については, 1998 年まで は $60 \mathrm{~Gy}$ を標準的に照射していたが, 1999 年から合併症 等に問題のない症例には, $66 \mathrm{G} \mathrm{y}$ に増量して照射を施行 している. 線量別の $\mathrm{CR}$ 症例の比率を比較したところ, 60 Gy：13.2\%，66 Gy：17.2\% と改善を示した. 5 生の比較 はまだできないが, $66 \mathrm{~Gy}$ 症例では MST 22 カ月, 2 生 $50.1 \%$ で, $60 \mathrm{~Gy}$ 症例の MST 12 力月, 2 生 $36.1 \%$ と比較 して良好であった。有害事象も骨髄抑制と放射線肺炎が やや強く認められたが, grade 4 の有害事象は認められず 許容範囲であったことから, 今後も $66 \mathrm{~Gy}$ を標準として いく予定である。

術前の induction therapy（以下 IT）は，化学療法や放 射線療法を術前に施行することで, 進行癌の down stage を図り，切除率の向上をめざすのが目的となる，非小細 胞肺癌の場合には，一般的に化学療法が施行され，局所 制御だけでなく術前から存在する顕微鏡レベルでの遠隔 転移の制御や術中操作による癌細胞の血中散布, 胸腔内 播種の制御が期待される. Roth ら14 や Rosell ら15 が術前 化学療法の有用性を報告している. Depierre ら16 は化学 療法を術前・術後に施行した群と施行しなかった群との 比較試験において, 両群間の生存期間には有意差は認め なかったが，生存期間の延長傾向を認めたと報告してい る. 当院では, 化学療法の有効性に加えて局所制御の向 上をも狙う目的で, IT の方法として CRTを用いて施行 してきた. そのため使用している抗癌剤のレジメンとし て, 肺障害が少なく放射線増感剂として期待でき，また 当時術前 CRT で多く使用されていた CDDP VP-16が 選択されていた。17-19 その結果, down stage の得られた 32 例に手術が施行され, 成績はMST 14 力月, 2 生 $40.2 \%, 5$ 生 $22.1 \%$ であった. 今回の報告は, 比較試験で 
はないことから単純な生存率の比較はできないが, CRT 群と手術群の生存率の比較では, 2 生の段階では手術群 が良好であるが, 5 生では有意差は認められなかった。 そ の原因の一つとしては, 術後経過中に 32 例中 16 例 (50\%) と高率に遠隔転移を来して抢り，それが死因と なっていたことである。これは, CRT 群の 82 例中 29 例 $(35.4 \%)$ と比較してもかなりの高率であった. CRT 群の場合には，局所再発の問題が常につきまとうことか ら一概に比較はできないが，今回手術群では局所再発例 は 1 例もみられておらず，その分の比率の上乗せが，高 率な遠隔転移として表れた可能性は考えられる，局所制 御の面から考えると, CRT は十分に効果的であったわけ だが，局所制御だけでなく術前から存在する顕微鏡レべ ルでの遠隔転移や術中操作による癌細胞の血中散布を制 御するという点では，十分な効果をあげることはできな かったと言える．また，CRT 群と手術群の生存率に有意 差がみられなかった別の原因としては，手術に関連した 合併症が 32 例中 10 例 (31.3\%) と高率に認められた点で ある。このうち，5例 $(15.6 \%)$ を気管・気管支瘦, 肺静 脈出血で失っている。実際，手術関連死を除外した成績 は, MST 15 力月, 2 生 $42.9 \%, 5$ 生 $23.6 \%$ と有意差はな いものの良い傾向にある．この原因としては術前の照射 線量を 60 Gy あるいは 66 Gy と full dose を施行してい た点に大きな問題があると思われる. Fowler ら20 は術前 に $60 \mathrm{~Gy}$ を照射し, 13 例中 3 例 $23.1 \%$ に術後の気管支瘦 の発生を生じたと報告している. Faber ら 21 は $40 \mathrm{~Gy}$ 照 射で $5 \%$, Yashar ら 18 は 55 Gy 照射で $9.7 \%$ と報告して おり, やはり線量の増加に伴い発生頻度も増加している 印象である.しかし，一般的に行われている $40 \mathrm{~Gy}$ 前後の 照射線量では, 十分な効果発現が得られない症例も多く, $40 \mathrm{~Gy}$ 照射以降に効果発現してくる症例が多くみられる ことから, down stage のことを考慮すると $50 \mathrm{~Gy}$ 以上の 照射線量は必要ではないかとも考えられる。現在，いく つかの術前 CRT のトライアルが行われているが，RTOG (Radiation Therapy Oncology Group) の ASCO 2003 (the 39 th annual meeting of the American Society of Clinical Oncology)での中間解析の報告では, Stage IIIA 症例に対 して術前 CRT 群と CRT 単独群との比較試験を行ってお り，それによると術前の照射線量は $45 \mathrm{~Gy}$ に設定してお り, 約 $7 \%$ が術後合併症で死亡していると報告している. その反面 $\mathrm{Ef3}$ の症例は $18 \%$ で，本報告の $34.4 \%$ と比較 するとやや不良である点は否めない. 今後の解析が待た れるところである。 なお，中間解析での生存率には術前 $\mathrm{CRT}$ 群と CRT 単独群では大きな差は認められておら ず，現在当院では正式な解析報告がなされるまでは術前 CRT は中止している.

最後になったが, 本治療は開始当初臨床試験としての
開始ではなく, CRT を当院での IT と考えて開始されて いた経緯があり，従って厳格な適格基準などは設定され ておらず，主治医の常識的な判断に委ねられていたのが 現状であった。当時のインフォームドコンセントも，本 治療法が新しい治療法ではあるが IT の一環であると位 置付け，期待できる効果と考えられる副作用について患 者様に説明し, 同意を得るのにとどまっていた.こういっ た経緯が関係して，年齢やPSにばらつきがみられたも のと思われる。しかし，1999年に照射線量を66 Gyに dose up をする段階で，それまでの当治療法の結果解析 と当時の報告のコンセンサスをふまえて適格基準を設定 した.また, 前述したように $60 \mathrm{~Gy}$ 以上照射した後の手術 は危険であるという判断から，CRTにより down stage が得られても，その後の手術は行わない方針とした。

現在の $\mathrm{CDDP}+\mathrm{VP}-16$ 使用 $\mathrm{CRT}$ の適格基準は以下の ごとくである.

\section{適格基準}

1）組織診または細胞診において非小細胞肺癌と診断 された症例。

2）前治療の行われていない症例.

3）切除困難で, 根治照射が可能な Stage II, III 症例.

4) PS が $0 \sim 1$ の症例.

5）年歯令は 20 歳以上 75 歳以下の症例.

6）以下の条件を満たす骨髄・肝・腎機能が保持され ている症例.

白血球数： $3000 / \mathrm{mm}^{3}$ 以上

血小板数: $75000 / \mathrm{mm}^{3}$ 以上

ヘモグロビン : $9.0 \mathrm{~g} / \mathrm{dl}$ 以上

GOT, GPT : 施設内正常值上限の 2 倍以下

BUN：施設内正常值上限

血清クレアチニン：施設内正常值上限

7）病名が告知されており, 本人による同意が得られて いる症例.

\section{除外基準}

1）治療を要する活動性の重複癌を有する症例.

2）重篤な心疾患 (コントロール困難な心不全，虚血性 心疾患，不整脈等）を有する症例.

3）重篤な肝疾患 (コントロール困難な肝不全, 肝硬変 等)を有する症例.

4）間質性肺炎や肺線維症などにより酸素投与が必要 な症例。

5）コントロール困難な糖尿病, 膠原病感染症を有する 症例.

6）妊娠中あるいは授乳中の症例, 妊娠の可能性のある 症例.

7）重篤な薬物アレルギーを有する症例. 
8）その他，担当医師が不適当と判断した症例. なお，適格基準を満たしていない場合でも，主治 医が可能と判断した場合には, CDDP 少量投与方法 で対応する.

以上, 当院での CRT についての報告を行ったが, 今後 は併用抗癌剂や多分割照射・強度変調放射線治療 (intensity modulated radiation therapy: IMRT) などの照射方法 の変更を行い,さらなる長期生存の可能性を検討してい く必要があると考えられた。

\section{REFERENCES}

1. Furuse K, Fukuoka M, Kawahara M, et al. Phase III study of concurrent versus sequential thoracic radiotherapy in combination with mitomycin, vindesine, and cisplatin in unresectable stage III non-small-cell lung cancer. J Clin Oncol . 1999;17:2692-2699.

2. Schaake-Koning $\mathrm{C}$, van den Bogaert W, Dalesio O, et al. Effects of concomitant cisplatin and radiotherapy on inoperable non-small-cell lung cancer. $N$ Engl J Med. 1992; 326:524-530.

3. Lau DH, Crowley JJ, Gandara DR, et al. Southwest Oncology Group phase II trial of concurrent carboplatin, etoposide, and radiation for poor-risk stage III non-smallcell lung cancer. J Clin Oncol . 1998;16:3078-3081.

4. Dillman RO, Seagren SL, Propert KJ, et al. A randomized trial of induction chemotherapy plus high-dose radiation versus radiation alone in stage III non-small-cell lung cancer. N Engl J Med . 1990;323:940-945.

5. Dillman RO, Herndon J, Seagren SL, et al. Improved survival in stage III non-small-cell lung cancer: seven-year follow-up of cancer and leukemia group B (CALGB) 8433 trial. J Natl Cancer Inst. 1996;88:1210-1215.

6. Sause WT, Scott C, Taylor S, et al. Radiation Therapy Oncology Group (RTOG) 88-08 and Eastern Cooperative Oncology Group (ECOG) 4588:preliminary results of a phase III trial in regionally advanced, unresectable non-smallcell lung cancer. J Natl Cancer Inst. 1995;87:198-205.

7. Sause W, Kolesar P, Taylor S, et al. Five-year results: phase III trial of regionally advanced unresectable nonsmall cell lung cancer, RTOG 8808, ECOG 4588, SWOG 8992. Proc Am Soc Clin Oncol . 1998;17:453a.

8. Le Chevalier T, Arriagada R, Quoix E, et al. Radiotherapy alone versus combined chemotherapy and radiotherapy in nonresectable non-small-cell lung cancer: first analysis of a randomized trial in 353 patients. $J$ Natl Cancer Inst. 1991;83:417-423.

9. Chemotherapy in non-small cell lung cancer: a metaanalysis using updated data on individual patients from
52 randomised clinical trials. Non-small Cell Lung Cancer Collaborative Group. BMJ. 1995;311:899-909.

10. Pritchard RS, Anthony SP. Chemotherapy plus radiotherapy compared with radiotherapy alone in the treatment of locally advanced, unresectable, non-small-cell lung cancer. A meta-analysis. Ann Intern Med . 1996;125:723729.

11. Marino P, Preatoni A, Cantoni A. Randomized trials of radiotherapy alone versus combined chemotherapy and radiotherapy in stages IIIa and IIIb nonsmall cell lung cancer. A meta-analysis. Cancer. 1995;76:593-601.

12. Curran WJ Jr, Scott C, Langer C, et al. Phase III comparison of sequential vs concurrent chemoradiation for PTS with unresectable stage III non-small cell lung cancer (NSCLC): initial report of Radiation Therapy Oncology Group (RTOG) 9410. Proc ASCO. 2000;19:484 a.

13. Kubota K, Tamura T, Fukuoka M, et al. Phase II study concurrent chemotherapy and radiotherapy for unresectable stage III non-small-cell lung cancer: long-term follow-up results. Japan Clinical Oncology Group Protocol 8902. Ann Oncol. 2000;11:445-450.

14. Roth JA, Fossella F, Komaki R, et al. A randomized trial comparing perioperative chemotherapy and surgery with surgery alone in resectable stage IIIA non-small-cell lung cancer. J Natl Cancer Inst. 1994;86:673-680.

15. Rosell R, Gomez-Codina J, Camps C, et al. A randomized trial comparing preoperative chemotherapy plus surgery with surgery alone in patients with non-small-cell lung cancer. N Engl J Med . 1994;330:153-158.

16. Depierre A, Milleron B, Moro-Sibilot D, et al. Preoperative chemotherapy followed by surgery compared with primary surgery in resectable stage I (except T1N0), II, and IIIa non-small-cell lung cancer. J Clin Oncol . 2002; 20:247-253.

17. Bonomi P, Faber LP. Neoadjuvant chemoradiation therapy in non-small cell lung cancer, the Rush University experience. Lung Cancer 1993;9:383-390.

18. Yashar J, Weitberg AB, Glicksman AS, et al. Preoperative chemotherapy and radiation therapy for stage IIIa carcinoma of the lung. Ann Thorac Surg. 1992;53:445-448.

19. Rusch VW, Albain KS, Crowley JJ, et al. Surgical resection of stage IIIA and IIIB non-small-cell lung cancer after concurrent induction chemoradiotherapy. A Southwest Oncology Group trial. J Thorac Cardiovasc Surg. 1993; 105:97-106.

20. Fowler WC, Langer CJ, Curran WJ, et al. Postoperative complications after combined neoadjuvant treatment of lung cancer. Ann Thorac Surg. 1993;55:986-989.

21. Faber LP, Kittle CF, Warren WH, et al. Preoperative chemotherapy and irradiation for stage III non-small cell lung cancer. Ann Thorac Surg. 1989;47:669-677. 